\title{
The Experimental Research of BTJF Medicated Serum Inhibiting on Growth of BXPC-3 Pancreatic Cancer Cell
}

\author{
Hu Bo ${ }^{1,2}$, Cheng Xin Sheng ${ }^{2}$, Wang Chun You ${ }^{3}$ \\ ${ }^{1}$ The postdoctoral research station of union hospital affiliated to TongJi medical college of Hua Zhong \\ university of science and technology (430022). \\ ${ }^{2}$ Number 8 hospital of Wu Han city of Hubei province (436000). \\ ${ }^{3}$ The union hospital affiliated to tongji medical college of Hua Zhong university of science and technology
} (430022).

*Corresponding Author: $\mathrm{Hu} \mathbf{B o}$, The postdoctoral research station of union hospital affiliated to TongJi medical college of Hua Zhong university of science and technology (430022).

\section{Abstract:}

Objective: To observe the effect of BUQI TONLUO JIEDU FANG (BTJF) medicated serum inhibiting on growth of BXPC-3 pancreatic cancer cell.

Methods: BTJF drug-containing serum and control group serum cultivate people BXPC3 pancreatic cancer cell in vitro respectively. By MTT method to, detect OD value of pancreatic cancer cells and the cell proliferation rate in each period, use flow cytometry instrument to detect serum the cell number of G0/G1, S, G2/M phase.

Results: Culture to 4 , the cell survival rate was $93.5 \%, P>0.05$, there was no significant difference in both groups; $24 h$, the cell survival rate was $71.2 \%, P<0.05$, the OD value in both groups have significant difference; $48 h$, the cell survival rate was $46.9 \%, P<0.05$, the $O D$ value in both groups have significant difference; $72 \mathrm{~h}$, the cell proliferation rate was $19.7 \%, P<0.01$, the $O D$ value was extremely significant difference in both groups. In S phase, The percentage in drug-containing serum group significantly lower than the blank control group, $P<0.05$, the two groups have significant difference, blank control group in G0/G1 phase cell percentage increased significantly, $P<0.05$, two groups have significant difference in statistics. $G 2 / M$ phase, compared two groups, $P>0.05$, no significant difference, the PI value in drugcontaining serum group was obviously lower than the control group, $P<0.05$, there is significant difference in both group.

Conclusion: BTJF medicated serum have significant effect of inhibiting the proliferation of human pancreatic cancer cell.

Keywords: Pancreatic cancer; Medicated serum; BXPC3; Cell proliferation

Pancreatic cancer is one of the high degree of malignant tumor, is one of the top ten malignant tumor of causing population death in our country. In recent years, the incidence of pancreatic cancer is gradually rising in worldwide; the mortality Close to morbidity, most patient have belong to middlelate phase after diagnosis, most patient died in six months [1-4].Traditional Chinese medicine is one of replacement therapy in treatment of pancreatic cancer, showing a good application prospect.

I have been using BTJF to treat locally advanced pancreatic cancer, has obtained the good clinical curative effect [5], and observed in the animal experiments that BTJF can reduce the incidence of HIC1 gene methylation, raised HIC1 gene expression, so as to exert the effect of inhibition on pancreatic cancer cell proliferation [6].In order to further observe their inhibitory effect on pancreatic cancer cells, I will act BTJF drug-containing serum on BXPC3 human pancreatic cancer cell, we will report the results of the study as follows: 


\section{EXPERIMENTAL MATERIALS}

Experimental animals and tumor strains: 10 healthy SD rats (male and female is half of ones respectively), only $6 \sim 8$ weeks of age, weight $250 \pm 59$, from Huazhong university of science and technology research center of tongji medical college of experimental animals, human pancreatic cancer cell line BXPC3, by union hospital affiliated to tongji medical college HuaZhong university of science and technology institute pancreatic disease.

\section{INSTRUMENTS AND REAGENTS}

Type SW - CT - 1 d single purification worktable Heraeus incubator

Type Olympus CKX41 inverted microscope Type SC - 3610 low speed centrifuge

No mycoplasma newborn calf serum 10122 Zhejiang hangzhou biological technology co., LTD Improved RPMI - 1640 culture medium NYL1029 Thermo Fisher biochemical products co., LTD UPLC liquid chromatograph American Waters AcquitylTM

Time of flight mass spectrometer

Acetonitrile (chromatography)

Methanol (chromatography)

Formic acid (chromatography)

Flow cytometry instrument

The cell cycle detection kit
American Waters LCT PremierXE

Germany, Merck company

American, Fisher company

Tianjin Kemiou chemical reagent co., LTD

American Becton Dickinson company (BD)

American BD company

\section{DRUGS AND PREPARATION}

BTJF are compose of ginseng $5 \mathrm{~g}$, radix astragali $30 \mathrm{~g}$, hovenia dulcis $10 \mathrm{~g}$, rhizoma ligustici wallichii, $15 \mathrm{~g}$, earthworm $10 \mathrm{~g}$, radix bupleuri $8 \mathrm{~g}$, centipede $3 \mathrm{~g}$, rhizoma zedoariae $15 \mathrm{~g}$, night shade of $15 \mathrm{~g}$, main licorice $6 \mathrm{~g}$.

According to the rat and man body surface area conversion method, equivalent dose is: people (70 $\mathrm{kg})$ : rats $(200 \mathrm{~g})=1: 0.018$. Daily dose calculation of traditional Chinese medicine compound each rats, $5 \mathrm{~d}$ dose calculation 5 rats. We will prepare 10 times herbal dose than the 5 rats of 5 day into 200 $\mathrm{ml}$ decoction ,used in the treatment group, 5 rats .each rat $4 \mathrm{ml}$ each time, 2 times a day, a total of $5 \mathrm{~d}$ to fill the stomach. The herbs soak 20 minutes with five times Herbs volume of cold water, and decocted with the strong fire until boiling, then decocted with the soft fire for 40min, Filter out the liquid, add cold water to Herbs, Fry until water boiling, slow fry 30 minutes, filter out dregs of a decoction, blending two Pharmaceuticals, and concentrated into Pharmaceuticals of every milliliter containing crude drugs $2 \mathrm{~g}$, saving in refrigerator from 0 to $4{ }^{\circ} \mathrm{C}$.

\section{Preparation of ChineSe Medicine dRUg-CONTAINING SERUM}

10 SD rats were randomly divided into 2 groups, 5 rat each group only. Treatment group and control group, respectively lavage with BTJF and saline. $4 \mathrm{ml}$ each time, 2 times a day, a total of 5 d.60-90 min after the last lavage, $10 \%$ chloral hydrate inject by intraperitoneal, $3.5 \mathrm{ml} / \mathrm{kg}$ dose, Draw blood from inferior vena after anesthesia, inserted in anticoagulation tube. Stand silence at room temperature for $30 \mathrm{~min}$, coagulation, serum separation. $3000 \mathrm{r} / \mathrm{min}$, the centrifugal after $20 \mathrm{~min}$, the supernatant is the drug-containing serum or blank serum. Same group serum mixed, with $0.22 \mu \mathrm{m}$ microporous membrane filter in order to Sterilizing, in - $20 \square$ saved for later use.

\section{MEDICATED SERUM COMPOSITION ANALYSIS}

Blank serum of rats and drug serum on the $0.5 \mathrm{~mL}$ sample to SPE column, activation balance with 2 $\mathrm{mL}$ methanol and $2 \mathrm{~mL}$ water in advance, drip washing with $4 \mathrm{~mL}$ water and $2 \mathrm{~mL}$ methanol, eluent abandon, elution again in $3 \mathrm{~mL}$ methanol, collect the eluent, air flow dry under $35 \square$, redissolve the residue with $100 \mu \mathrm{L}$ mobile phase, ultrasonic 1 minute, after the suspension shock the $30 \mathrm{~S}, 4 \square, 13$, $000 \mathrm{r}$. centrifugal 10 minute, take supernatant liquid, sample $2 \mathrm{~mL}$ for UPLC analysis. 


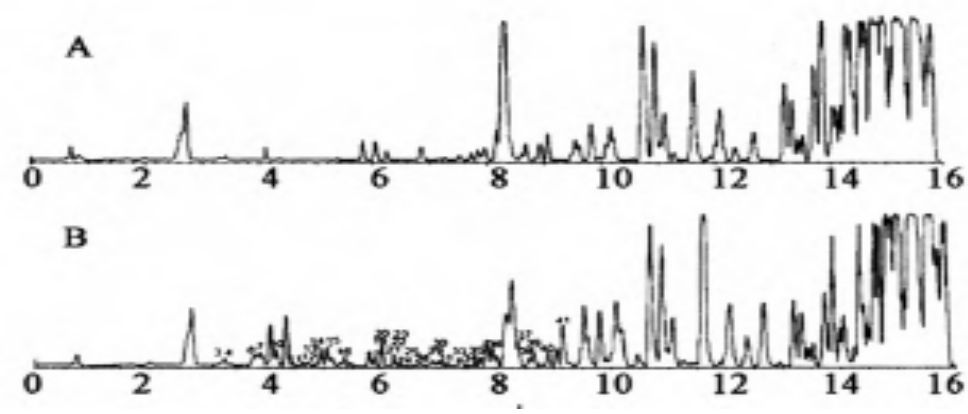

Note: A: blank serum group, B: drug-containing serum group

Results showed that after the rat taken BTJF, 12 blood transitional components are made up of five metabolism components and seven prototype components. in the composition of the prototype, three from ginseng, 2 from the centipede, 1 from rhizoma zedoariae, 1 from solani; Nothing been found from radix bupleuri, bitter orange, astragalus root, rhizoma ligustici wallichii, earthworm and main licorice in the blood components.

\section{Cell Culture}

After pancreatic cancer cell line BXPC-3 recover, abandon the nutrient solution, add pancreatic enzyme $2 \mathrm{ml}$, It placed in the incubator for 5 minutes, add $2 \mathrm{ml} \mathrm{10 \%} \mathrm{calf} \mathrm{serum} \mathrm{RPMI1640} \mathrm{culture}$ solution, then put it into EP, centrifuge at a speed of $1000 \mathrm{RPM} / \mathrm{min}$ for 5 minutes, abandon supernatant, add $2 \mathrm{ml}$ culture solution, and culture in incubator in saturated humidity at $37 \square$ and $5 \%$ $\mathrm{CO} 2$.

\section{DETECT CELL PROLIFERATION BY MTT METHOD}

With $10 \%$ calf serum RPMI1640 culture, diluted logarithmic growth phase cells into $2.5 \times 10^{4} / \mathrm{ml}$ of cell suspension, inoculated in 96 - well plates, $200 \mu 1$ each hole, cultivate $24 \mathrm{~h}$. after cells stayed adherent. abandon culture solution, then add $180 \mu 1$ drug-containing serum or blank serum cultures solution respectively. In $0 \mathrm{~h}, 20 \mathrm{~h}, 44 \mathrm{~h}, 68 \mathrm{~h}$, add $20 \mu 1$ MTT each hole to cultivate for $4 \mathrm{~h}$, abandon culture solution, add $150 \mu 1$ dimethyl sulfoxide (DMSO) each hole, and shock 10 minutes, after it have been completely dissolved, read the absorbance (OD value) by enzyme-linked immunometric meter at $570 \mathrm{~nm}$ wavelength zeroing. 10 Repeat whole each time each group. Other, set three zeroing hole respectively each group (no vaccination cells, and the rest steps follow experimental hole). According to the following formula to calculate the cell survival rate, survival rate = [(medicated serum hole OD value - medicated zeroing hole OD value)/(control serum hole ODcontrol zeroing OD value)] $\times 100 \%$, The results are shown in table 1 .

\section{DETECT THE CELL CYCLE BY FLOW CYTOMETRY}

With PBS, adjust logarithmic phase cells concentration to $1 \times 10^{6} / \mathrm{ml}$. Sample $100 \mu \mathrm{L}$, place in the corresponding FALCON tube, add $250 \mu \mathrm{L}$ solution A each tube, blending gently, place for 10 minutes at the room temperature. add $200 \mu \mathrm{L}$ solution B Each tube, gently blending. place for 10 minutes at the room temperature. add $200 \mu \mathrm{L}$ solution $\mathrm{C}$ Each tube, gently blending, in low temperature (2-8 $\square)$ avoiding light, place for 10 minutes. Filter cells With 35 um filter. Open the flow cytometry instrument to test. Use Cell Quest software to collect cells, Mod Fit software analyse DNA data, read the G0 / G1, S, G2 / M phase of cell number. The diagram below:
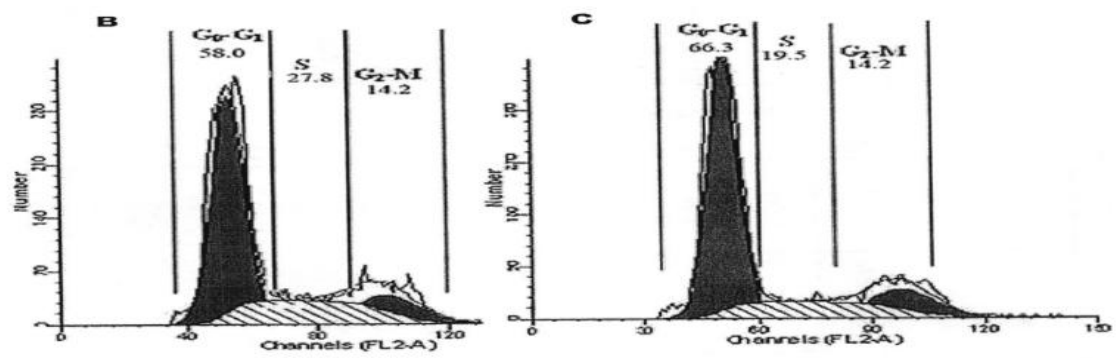
According to the formula to calculate the proliferation index: $\mathrm{PI}=(\mathrm{S}+\mathrm{G} 2 / \mathrm{M}) /(\mathrm{G} 0 / \mathrm{G} 1+\mathrm{S}+\mathrm{G} 2 /$ M) $\times 100 \%$, The results are shown in table 2 .

\section{STATISTICS ANALYSIS}

The experimental results are expressed in $X \pm s$, measurement data using two independent sample ttest, much difference compared using analysis of variance among groups (one way ANOVA), using SPSS 10.0 software package to process data with $\mathrm{P}<0.05$ for significant standard.

\section{RESULTS}

Table1. BTJF drug-containing serum influence on BXPC - 3 pancreatic cancer cells $O D$ value

\begin{tabular}{|l|l|l|l|l|}
\hline & $4 \mathrm{~h}$ & $24 \mathrm{~h}$ & $48 \mathrm{~h}$ & $72 \mathrm{~h}$ \\
\hline Drug-containing serum group & $0.476 \pm 0.312$ & $0.452 \pm 0.266$ & $0.399 \pm 0.174$ & $0.253 \pm 0.114$ \\
\hline Control serum group & $0.473 \pm 0.299$ & $0.636 \pm 0.331$ & $0.927 \pm 0.488$ & $0.857 \pm 0.117$ \\
\hline Cell survival rate $(\%)$ & 93.5 & 71.2 & 46.9 & 19.7 \\
\hline
\end{tabular}

By $\mathrm{T}$ test, in $4 \mathrm{~h}$, the cell survival rate was $93.5 \%, \mathrm{P}>0.05$, there are no significant difference in both groups of OD value; $24 \mathrm{~h}$, the cell survival rate was $71.2 \%, \mathrm{P}<0.05$, the $\mathrm{OD}$ value in both groups have significant difference; $48 \mathrm{~h}$, the cell survival rate was $46.9 \%, \mathrm{P}<0.05$, the OD value in both groups have significant difference; $72 \mathrm{~h}$, the cell proliferation rate was $19.7 \%, \mathrm{P}<0.01$, there are extremely significant difference in both group of the OD value.

Table2. BTJF drug-containing serum influence on BXPC - 3 pancreatic cancer cell cycle distribution

\begin{tabular}{|l|l|l|l|l|}
\hline & $\mathrm{G} 0 / \mathrm{G} 1(\%)$ & $\mathrm{S}(\%)$ & $\mathrm{G} 2 / \mathrm{M}$ & $\mathrm{PI}$ \\
\hline Control serum group & $63.5 \pm 1.8$ & $24.2 \pm 1.4$ & $12.3 \pm 2.3$ & $36.5 \pm 2.7$ \\
\hline Drug-containing serum group & $72.6 \pm 2.3$ & $15.8 \pm 2.0$ & $11.6 \pm 2.6$ & $27.4 \pm 3.1$ \\
\hline
\end{tabular}

By $\mathrm{T}$ test, the percentage of period $\mathrm{S}$ in the drug-containing serum group is significantly lower than the control serum group, $\mathrm{P}<0.05$, the two groups have significant difference, the cell percentage of phase G0 / G1 in control serum group increased significantly, $\mathrm{P}<0.05$, both groups have significant difference in statistics. In phase G2 / M, compared two groups, P > 0.05, no significant difference, the PI value of drug-containing serum group was obviously lower than the control serum group, $\mathrm{P}<0.05$, there are significant difference.

\section{DISCUSSION}

In the 1980s, Japanese scholars Iwama [7] firstly put forward "serum pharmacology method". This method is to use Chinese medicine to fill the stomach for animals, after a certain time, collecting animal blood serum and separate it, use medicated serum in vitro experiments. This method not only prevents the physical and chemical properties of traditional Chinese medicine itself interrupt to vitro experiment, and simulates the drug influence on cell biology properties in the body, Not only reflects direct effect of the part drug can absorbing, but also can reflect the metabolism material of drugs in the body and the indirect effects of drug induced the body to produce endogenous substances, realized the perfect combination of in vitro and in vivo experiment.

In the experiment, by BTJF drug-containing serum and control serum respectively culture BXPC - 3 pancreatic cancer cell line in vitro, we observe that the cell proliferation rate was $93.5 \%$, in $4 \mathrm{~h}, \mathrm{P}>$ 0.05 , there was no significant difference in both group OD values; After it, cell survival rates of drugcontaining group drop sustained, and $72 \mathrm{~h}$, the OD value of drug-containing serum group was obviously lower control serum group, $\mathrm{P}<0.01$, the two groups have significant differences, cancer cell survival rate drop to $19.7 \%$ at the same time, It show drug-containing serum inhibit the growth of cancer cells reaching the peak at this time.

Flow cytometry were used to detect the situation of BTJF drug-containing serum intervening cell cycle. The situation shows that the percentage of phase $\mathrm{S}$ cells in drug-containing medicine serum group was obviously lower $(\mathrm{P}<0.05)$, the cell percentage of phase G0 / G1 increased significantly, and by calculating the proliferation index (PI) ,It also showed that the proliferation index of drugcontaining serum group decreased $(\mathrm{P}<0.05)$, suggesting BXPC -3 cell proliferation is restrained. 


\section{REFERENCES}

[1] Alexakis $\mathrm{N}$, Halloran $\mathrm{C}$, Raraty $\mathrm{M}$, et al. Current standards of surgery for pancreatic cancer. $\mathrm{Br} \mathbf{J}$ Surg, 2004, 91 (11): 1410-1427.

[2] Raut CP, Evans DB, Crane CH, et al. Neoadjuvant therapy for respectable pancreatic cancer. Surg Oncol Clin North Am, 2004, 13 (4): 639-661.

[3] Brennan MF. Adjuvant therapy following resection for pancreatic adeno-carcinoma. Surg Oncol Clin North Am, 2004, 13 (4): 555-566.

[4] Goldstein D, Carroll S, Apte M, et al. Modern management of pancreatic carcinoma. Int Med J, 2004, 34 (8):475-481.

[5] Hu Bo, Wan Xi Chong, Qiu Xing Fan etc. mechanism study of BTJF regulating SHH signaling pathways of pancreatic cancer model mice [J]. Practical combine traditional Chinese and western medicine clinical magazine, 2010.10 (5): 88-89.

[6] Hu Bo, Chun You Wang, The Experimental study of BTJF influencing on HICI methylation level of pancreatic cancer model mice [J]. Chinese Journal of Integrative Medicine, 2013 (7): 963-966.

[7] Iwama H. Effect of shosaikoto, a Janpanese and Chinese traditional herbal medical mixture on the mitogenic activity of lipopolysaccharide: A new pharmacology testing method. J Ethnopharmacal, 1987, 21(1):45-53.

Citation: H. Bo et al., "The Experimental Research of BTJF Medicated Serum Inhibiting on Growth of BXPC3 Pancreatic Cancer Cell", International Journal of Clinical Chemistry and Laboratory Medicine (IJCCLM), vol. 4, no. 1, pp. 1-5, 2018. http://dx.doi.org/10.20431/2455-7153.0401001

Copyright: () 2018 Authors. This is an open-access article distributed under the terms of the Creative Commons Attribution License, which permits unrestricted use, distribution, and reproduction in any medium, provided the original author and source are credited. 